\title{
CRIMINAL LIABILITY OF LEGAL PERSONS IN BOSNIA AND HERZEGOVINA AND CROATIA
}

Debate whether legal persons can be criminally liable has been subject of academic interest and discussions for a long time. Led by Latin phrase "societas delinquere non potest", the vast majority of legal systems did not accept criminal liability of legal persons for a long time. The key argument for this viewpoint was the lack of „mens rea” element (the "guilty mind" or intention of an individual). Yet, it would be unfair to say that legal persons were not responsible for breach of law in any other way. Legislation of the Former Republic of Yugoslavia recognized economic transgressions as a separate category of criminal offence. After the dissolution of the Former Republic of Yugoslavia, all member states showed commitment to European integration. In order to join the European Union, candidates for future membership had to harmonize national law with "acquis communautaire" and consequently introduced criminal liability of legal persons in criminal and criminal procedure codes. In the paper, besides the historical background, the author analyzes differences and similarities between criminal liability of legal persons in Bosnia and Herzegovina and Croatia, focusing on specific features of criminal proceedings against legal persons. Both countries adopted a model of derived, subjective and cumulative liability. Author compares differences between specific matters of criminal procedure against legal persons. The issue that deserves special attention in the context of derived liability of legal persons is whether a natural person and a legal person can have joint defense. Besides specific features of a criminal procedure against legal persons, the paper also elaborates different regulation of sanctions, security measures and consequences of conviction for against a legal person. Finally, in the conclusion, the author advocates intervention in B\&H legislation, following the solutions prescribed by the Law on the Liability of Legal Persons for Criminal Offenses regarding joint and mandatory defense, and, especially, for establishing of a public criminal register of convictions against legal persons. Public

* Teaching assistant at the Law School of Sarajevo University, external research assistant in Foundation Public Law Centre. Email: e.gotovusa@pfsa.unsa.ba. 
criminal register of convictions against legal persons has a vital role in national economy, having in mind that legal persons are most common users of financial services.

Key words: criminal liability of legal person, model of derived liability, joint defense of legal person, mandatory defense of legal person, public criminal register of convictions against legal persons.

\section{INTRODUCTION}

The change in the social and economic system, the transition from socialism to capitalism that took place in the territory of former Social Federal Republic of Yugoslavia (hereinafter SFRY) in the last decade of the 20th century, influenced development of new norms of criminal liability of legal persons. The revision process of the provisions of substantive and criminal procedural law in the six former republics of SFRY was enhanced by the efforts to join European integrations. After the end of the war activities in the 90ies, all of the states of former SFRY, with no exception, expressed their determination to become EU members. The process of EU association requires implementation of acquis communautaire ${ }^{306}$. More precisely, it is the Second Protocol based on Article K 3 of the European Treaty to the Convention on the protection of financial interests of the European communities from 1997, which prescribes criminal liability of legal persons in cases of fraud or bribery, or money laundering, perpetrated in their own interest, which inflicts, or may inflict, damage to the financial interests of the European Communities. ${ }^{307}$ Another document, which is also significant besides the Protocol, is the Framework Decision of the Council on strengthening of criminal legislative framework for the implementation of the legislation against ship-source sea pollution.$^{308}$ What makes this Decision specific is reflected in the fact that the European Union recognized the necessity of common sanctions against legal persons for criminal offences inflicted against the environment.

However, it would be unfair to claim that the criminal liability of legal persons for criminal offences is a novelty brought by the process of accession to the EU of former SFRY republics. This issue was considered by the academic community much earlier than it could have been deemed that the former SFRY republics would become EU candidates or member states. The authors of the Criminal law of SFRY textbook (Srzentić \& Stajić, 1961, p. 9, Srzentić, Stajić \& Lazarević, 1984, p. 14) compared the nature of violations committed by legal persons as criminal offences with those committed by natural persons. Consequently, the introduction of criminal liability of legal persons into the criminal

\footnotetext{
306 The reference implies collection of shared rights and obligations by all member states. It is mandatory for all candidate states for membership in the EU to incorporate acquis communautaire in their respective national rule of law by the accession date and to start imlementing it thereof.

307 The Convention and the Second Protocol were replaced by the European Parliament and the Council Directive (EU) 2017/1371, July 5, 2017, on the fight ofagainst fraud to the Union's financial interests by means of criminal law.

${ }^{308}$ The Decision was amended by the adoption of the Directive 2005/35/EZ by the European Parliament and the Council of 7. 9. 2005 on ship-source pollution and on the introduction of penalties for infringements to be replaced by the EU Directive 2009/123/EZ by the European Parliament and the European Council of 21. 10. 2009.
} 
legislation of former SFRY republics is not a novelty in the legislative tradition they all share. (Derenčinović \& Novosel, 2012, p. 585).

The present paper is divided in three parts. The first part is a background of the development of the concept of criminal liability of legal persons in Bosnia and Herzegovina and Croatia. The second part deals with basic similarities and distinctions in the legal arrangements of the matter, whereas the third part deals with specific features of criminal procedures against legal persons for the purpose of comparative analysis.

\section{DEVELOPMENT OF CRIMINAL LIABILITY CONCEPT IN BOSNIA AND HERZEGOVINA AND CROATIA}

The initiative to introduce criminal liability of legal persons into the substantive criminal law of the Federal People's Republic of Yugoslavia emerged as early as 1951 (Perić\&Obrad, 1986, p. 21). Although the Draft of the Criminal Code of 1951 contained provisions on criminal liability of legal persons, they were ultimately abandoned. According to Zlatarić, criminal liability of legal persons should have been prescribed by a special law, taking into account the criteria distinguishing the conduct of individuals, and that of legal persons, as criminal liability from administrative transgression. (Zlatarić, 1955, p. 49). With the establishment of economic (commercial) courts in 1954, legal persons, i.e. their responsible persons were held liable for economic breaches prescribed by numerous provisions (Zlatarić, 1955, p.65, footnote 32). The consolidation of substantive and procedural regulations prescribing specific punishable offences in economy committed by legal persons resulted in the adoption of the Law on economic transgressions in 1960 (Lawon Corporations). The Law prescribes economic transgression as an act of violation of the rules in economic and financial transactions by economic entities and other legal persons that caused or may have caused serious consequences and that were prescribed as an economic transgression, by a competent authority,. The nature of economic transgressions that were regulated in such a manner was a subject of considerations by the academic community. Srzentić and Stajić (1961, p. 9), for example, state that economic transgressions have much greater likeness to criminal offences because it can be concluded that economic transgressions are, to a certain extent and in certain areas, socially threatening acts, despite the fact that the legal definition of economic transgressions does not include a threat to the society as an element of criminal offense, and that they are rather violations of economic or financial disciplines that have caused or may have caused serious consequences. Such explanation could lead us to a justified conclusion that economic transgressions are criminal offenses sui generis. The additional similarity between an economic transgression and a criminal offense is reflected in the fact that, in the case of an economic transgression, in terms of the procedure, it is the court of law that is the competent authority which decides on pecuniary penalty, as it is an exclusive criminal sanction. The authors, finally, highlight that, in cases where there is a liable person in a legal person or a corporation, such person shall be charged with a criminal offence and not with an economic transgression; this is due to the fact that legal persons cannot, legally speaking, commit criminal offences or be held liable for them. (Srzentić \& Stajić, 1961, p. 10) 
Such legal regulation of economic transgressions, unintentionally served as a basis for the introduction of liability of legal persons into the criminal legislations of Bosnia and Herzegovina and Croatia at the beginning of the first decade of 2000.

After the dissolution of SFRY, Bosnia and Herzegovina and Croatia took over the Law on Corporations. The adoption of the laws on minor offences in the two countries resulted in economic transgressions being renamed as minor offenses. In 2003, criminal liability of legal persons was introduced for the first time in the criminal legislation in Bosnia and Herzegovina with the adoption of Criminal Code (hereinafter $\mathrm{CC} \mathrm{BiH}$ ) and the Criminal Procedure Code of Bosnia and Herzegovina (hereinafter $\mathrm{CPC} \mathrm{BiH}$ ). In september of the same year, in September, the Republic of Croatia adopted the Law on the Liability of Legal Persons for Criminal Offences (hereinafter LLPCO) .

\section{FUNDAMENTAL SIMILARITIES AND DISTINCTIONS}

When speaking about criminal liability of legal persons in Bosnia and Herzegovina and Croatia, the first, evident distinction lies in the manner it has been regulated. The Republic of Croatia decided to regulate criminal liability of legal persons by a lex specialis (LLPCO) and subsidiary enforcement of the provisions of the Criminal Code, Criminal Procedure Code and the Law on the Office for the Suppression of Corruption and Organized Crime. Unlike Croatian solution, substantive and procedural provisions on criminal liability of legal persons in Bosnia and Herzegovina are prescribed in separate chapters of lex generalis: theCriminal Code and the Criminal Procedure Code. Regardless of the differences in legislative policies, both countries adopted the model of derived criminal liability of legal persons. Based on this model, criminal liability of a legal person is derived from the criminal liability of a natural person. It is the status, i.e. the powers that a natural person may have in a legal person that creates the first distinction between the two legislations. According to the Article 3 of LLPCO, a legal person shall be punished for a criminal offense committed by a responsible person in a legal person, if such criminal offence inflicts damage to the duty of the legal person or, if the legal person acquired or was toacquire illegal personal benefit or benefit on behalf or for the benefit of another person. Consequently, sanctioning of a legal person must be preceded by finding the natural person, having the status of a liable person, guilty. The grounds for finding legal persons liable for criminal offences are somewhat wider in the $\mathrm{CC} \mathrm{BiH}$. The natural person will be find liable if he or she has committed a criminal offense on behalf of or for the benefit of thelegal person in the following cases: a) when the substance of the criminal offense derives from a conclusion, an order or approval/authorisation by managing or supervising body of the legal person; b) or, when the managing or supervising bodies of the legal person influenced the perpetrator, or made it possible for the perpetrator, to commit the offence; c) when a legal person disposes with illegally acquired financial benefit or uses objects acquired by the criminal offense; d) when managing or supervising bodies failed to duly carry out supervision over the legality of work of the employees. Furthermore, the authorisation of a certain person to act, on behalf or for the benefit of a legal person, as well as the scope of action that she/he is authorised to undertake, may be derived from the law or any legal 
provision or internal regulation, individual document or agreement concluded between the perpetrator an the legal person (Filipović \& Ikanović, 2012, p. 29).

In previously mentioned cases, the perpetrator may not necessarily have a leading position in the legal person which implies being vested with the general authorization to represent it, to make decisions on its behalf, or to have supervising powers. Such a person does not necessarily have to be a member of the legal person/entity, its employee, in order to be found criminal liable. Naturally, any exhibit of evidence on criminal liability of a legal person will be much easier if there is formal and legal authorization given to the perpetrator to undertake given actions. This does not imply that this is the exclusive case where criminal proceedings will be instituted.. Criminal liability of a legal person will also exist in case the court finds that the perpetrator was practically authorized to undertake actions on behalf of the legal person or for its benefit (Filipović \& Ikanović, 2012, p. 29).

The existence of legal or true obstacles in determination of guilt of a liable person, i.e. natural person liable for committing a criminal offence on its behalf, or in its interest or for its benefit, does not imply abandoning of criminal action against the legal person. The exception is identical both in the LLPCO and CPC BiH. It is worth mentioning, at this point, that it is possible to bring charges and pronounce conviction against the legal person even though it is impossible to identify the perpetrator, provided that there are sufficient evidence for reasonable suspicion that an criminal offense was committed (Filipović \& Ikanović, 2012, p. 43). The difference in definitions of the status (liable person) and the authorizations (act on behalf, in the interest, for the benefit) of a natural person, who is the perpetrator and whose offence is a presupposition for sentencing the legal person, is the basic difference in the analysed legal texts. Responsible or liable person is a natural person in charge of conducting business of a legal person, or is in charge of conducting business in the field of its business activity (Article 4 of the LLPCO). Likewise, the CC $\mathrm{BiH}$ includes the definition of a liable person which, inter alia refers to the position and authorizations of a natural person within the legal person (Article 1, paragraph 5 of the $\mathrm{CC} \mathrm{BiH})$. However, the legislator, regardless of this fact, does not refer to it in prescribing criminal liability of legal persons.

Certain distinctions and similarities in prescribing and enforcement of criminal sanctions against legal persons, as well as the application the principle of opportunity can be noticed. Both legislations provide the following as main sanctions: fine and termination of legal person. The $\mathrm{CC} \mathrm{BiH}$, additionally, prescribes seizure of property and dispossession of legal persons. The conditions for pronouncing suspended sentence instead of a fine, may vary. It is possible to pronounce a suspended sentence, if a fine of less than 50.000,00 HRK (approximately 13.000,00 BAM) is pronounced against the legal person with probation period from one to three years. (Article 13 of the LLPCO -a). Nevertheless, although the term of prescribed probation by the $\mathrm{CC} \mathrm{BiH}$ is longer - amaximum of five years - the amount of the fine in case of a suspended sentence is 115 times higher (Article 136 of the $\mathrm{CC} \mathrm{BiH}$ ). The legal norms are different when it comes to the issue of security measures. In Croatian legislation, prohibition of conducting certain activities or affairs, prohibition of acquiring licenses, authorizations, concessions or subventions, as well as prohibition of conducting business affairs with national or local budget beneficiaries are treated as security measures. 
In $\mathrm{BiH}$ legislation, the prohibition to operate based on a license, authorization or concession issued by a foreign state, as well as prohibition to operate based on a license, authorization or concession issued by $\mathrm{BiH}$ institutions, is foreseen as a possible legal consequence of a conviction against a legal person in case of committing a criminal offence. Seizure of objects (dispossession) from a legal person, prohibition of certain activities and affairs are security measures envisaged in both legislations. Additionally, the $\mathrm{CC} \mathrm{BiH}$ prescribes the public announcement of the verdict as a security measure. Public announcement of the verdict based on Article 21 of the LLPCO is separately regulated. Dispossession of illicit gains, as a sui generis measure is foreseen by both laws.

However, entirely different solutions are foreseen when it comes to the statute of limitations (enforcement of sanction, i.e. termination of legal person). In Croatia, the sanction can be enforced at any time, given that its enforcement is not subject to the statute of limitations by law. In Bosnia and Herzegovina, on the contrary, the statute of limitations applies to legal persons, and it amounts to five years afterthe legal validity of the court ruling. Finally, LLPCO prescribes that it is the duty of the Court, upon its judgement convicting of a legal person, to inform without delay the Court Register, or any other register where the legal person may have been registered, as well as the Ministry of Justice. Such an ex officio action by the Court is not foreseen in the criminal legislation provisions in Bosnia and Herzegovina simply because there is no register of court penalties against legal persons. In the author's opinion, this is a major failure, which has considerable consequences in the real economy life. The existence of such a register would have a multiple benefit in allocating bank loans or participating in public bids.

The principle of opportunity is foreseen by both legislations. A prosecutor may have decide not to press charges and institute court proceedings against a legal person when there is circumstantial evidence indicating that there is no property, or where the property at stake is not sufficient to cover even the costs of the proceeding, or if bankruptcy procedure is instituted against the legal person. Furthermore, the $\mathrm{CPC} \mathrm{BiH}$ prescribes the power of the prosecutor not to institute criminal proceedings in cases when a contribution of a legal person to the commitment of a criminal offense is insignificant, or when the perpetrator is the sole owner of the legal person. In this manner the legislator excluded the possibility to punish the same natural person twice: once, as a natural person for committing criminal offence, and the second time, as a legal person, the exclusive owner of the legal person (Sijerčić-Čolić et al, 2005, p. 927).

After this brief review of the similarities and distinctions in regulating liability of legal persons, the author will deal with some of the specific features of criminal proceedings against legal persons for criminal offenses in Bosnia and Herzegovina and Croatia.

\section{SPECIFIC FEATURES OF CRIMINAL PROCEEDINGS/PROCEDURES AGAINST LEGAL PERSON: BOSNIA AND HERZEGOVINA AND CROATIA}

Legal persons do not have rights and obligations granted and inherent to natural 
persons ${ }^{309}$. They do not possess mental capacity of memorizing, observing or giving statements (Đurđević, 2003, p. 757). However, these distinctions do not affect their status of a party to a criminal proceeding. They only result in the necessity to adjust provisions of a criminal proceeding against an individual to the proceeding against the accused/ charged legal person. Given the adopted model of the derived liability, which stems from the inseparable liability of a legal person for criminal offence from criminal liability of natural person who is a liable person or acted on his/her behalf, benefit or interest. Against this background, the adjustments are reflected in:

1. Joint criminal proceedings/procedure against liable natural person and legal person;

2. Involvement of a representative of a legal person;

3. Involvement of defence lawyer of a legal person;

4. Specific features of the course of the main hearing.

\subsection{Joint criminal proceeding/procedure}

Joint criminal proceedings/procedure against a legal and liable person, or natural person acting on its behalf or in its interest or to its benefit is justified for two reasons. Firstly, it would satisfy the principle of efficiency. If the evidence to prove the causal link between the criminal offender (liable person/natural person) and the legal person, which consists of either harm to the duty or, in realization of illicit financial gain of the legal person, does not exist, the legal person shall not be held guilty for the criminal offence (Sijerčić-Čolić et al, 2005, p. 926). Secondly, it is much easier for the court to establish criminal liability of a natural/liable person and legal person if it comprehensively and in "one place" considers all the evidence and facts in order to find the causal connection.

The present solution has been adopted by both legislations, with prescribed exceptions.In Croatia, criminal proceedings against legal persons will be instituted when it is not possible to institute criminal proceeding against the liable person due to legal or other reasons. A similar, albeit somewhat modified provision is included in the $\mathrm{CCP} \mathrm{BiH}$. In addition to the identical exception, it possible to institute, i.e. to conduct, criminal proceedings against legal persons even in the case where criminal procedure against natural person has already been finalized.

The analysis of relevant provisions in the legislations of Bosnia and Herzegovina and Croatia leads us to a single conclusion that it would be most purposeful to have a joint criminal proceeding/procedure against the criminal offender and legal person due to the derived nature of criminal liability of a legal person. However, the prescribed exceptions indicate that the state insists on its ius puniendi, even in cases where it is not possible to conduct, due to legal, or realistic obstacles, criminal proceeding against a natural person which, eventually, would result in sanctioning a legal person. The question that remains open for those who deal with this issue in practice, is whether it will be possible to determine the responsibility of a legal person for criminal offense in such a case.

309 This refers to the rights that natural persons have pursuant to the Constitutional provisions, national legislation and international conventions and treaties. 
A representative of a legal person in a criminal proceeding is a natural person who represents criminal law subject not inherent to individual criminal proceedings. He/she does not have the status of accused individual and acts only for the purpose of defence (Filipović \& Ikanović, 2012, p. 77). The obligation to determine a legal person representative and the conditions to be satisfied for this procedural role are foreseen by both legislations. The representative of a legal person is a person authorized to represent a legal person by law, an act by competent state authority, statute, charter of foundation or any other act by a legal person (Bosnia and Herzegovina), or by person authorized by the authorities of a legal person, i.e. persons representing it based on the law, decision of a competent body, statute, social agreement or a decision by a legal person (Croatia). Whereas the provisions of the $\mathrm{CPC} \mathrm{BiH} \mathrm{(Article} \mathrm{378,} \mathrm{paragraph} \mathrm{1)} \mathrm{prescribe} \mathrm{for} \mathrm{the} \mathrm{representative} \mathrm{to} \mathrm{be} \mathrm{a} \mathrm{person}$ with power to represent legal person based on the law, act of a competent state authority or the statute, charter of foundation or any other act by a legal person, entailing that the powers of the representative have already been established by a regulation/internal act, the LLPCO (Article 27) leaves this to the body of a legal person or a person authorized to represent the legal person, to determine who the representing person will be.

The distinction in the legal provisions may be disregarded given the fact that the power of an individual to act on behalf, in the interest or to the benefit of the legal person in legal transactions in dealing with other natural and legal persons is differently addressed by other norms. Based on the LLPCO and the CPC BiH, a legal person can have only one representative. It is the duty of the court conducting a criminal case to ascertain the identity of representative and her/his authorization to take part in the case before the court. Both laws prescribe a triple ban on individuals who may act as a representative of a legal person. Accordingly, a representative cannot be the same individual invited in the capacity of a witness, a person against whom the same criminal proceeding is instituted, or a defence counsel (Article 382 of the CCPBiH and Article 27, paragraph 5 of the LLPCO). Based on the CPC BIH provisions, the cumulative role of both an accused person and the representative of an accused legal person is permitted only in case where the accused person is, at the same time, the only member of a legal person. This procedural issue is not recognized in the LLPCO.

The court has the power and the duty to appoint a representative to a legal person, if the legal person had appointed the representative contrary to the mentioned conditions, upon the expiry of the reasonable time for appointing another representative (Article 28, paragraph 4 of the LLPCO and Article 379, paragraph 3 of the CPC BiH).

The key distinction in addressing the rights and obligations of the representative of a legal person in criminal proceedings against legal persons is that the Court may decide to hold the hearing, after the legal person has pleaded guilty/innocent, in absence of the representative who has been duly summoned but whose presence is not ultimately necessary (Article 34, paragraph 4 of the LLPCO). The $\mathrm{CPC} \mathrm{BiH}$, however, does not recognize this option. The presence of the representative is mandatory (Article 377, paragraph 1 of the $\mathrm{CPC} \mathrm{BiH})$. 


\subsection{Defence counsel of a legal person in criminal cases}

The right of a legal person to have a defence counsel in addition toa representative, is optional. However, the issue of whether a legal person and a liable/natural person may share the same defence counsel, is addressed differently. A legal and liable person may have the same defence counsel if the same criminal case is at stake (same criminal offense) and if it is not in contradiction with their defence (Article 32 paragraph 2 of the LLPCO). The arguments by Croatian legislator are that it should be permitted to both a legal person and a liable person to have the same defence counsel because there will always be one criminal procedure for the same criminal offense, and if a liable person is successful in the defence, this will constitute a successful defence for the legal person as well (Đurđević, 2003, p. 763). Contrary to the above, the CPC BiH explicitly forbids that the legal and natural persons as suspects, i.e. the accused persons, have/share the same defence counsel. According to the Commentaries to the $\mathrm{CCP} \mathrm{BiH}$, the engagement of the same defence counsel is not justified because there is a realistic possibility for a collision between the interests of a natural and legal person when the same criminal proceeding is held simultaneously (Sijerčić-Čolić et al, 2005, p. 932). However, the above position is ill-founded because of the derivative nature of the liability of the legal person, which is derived from criminal liability of a natural person acting on its behalf, in its interest, or for its benefit. This is not contested by the authors of the Commentaries to the $\mathrm{CPC} \mathrm{BiH,}$ who recognise that the accused natural person is the central figure and the reason why she/he should be given priority rather than the representative of a legal person at the main hearing (Sijerčić-Čolić et al, 2005, p. 933). Based on the above position of the authors, the natural person should have priority at the main hearing, because the liability of the legal person rests on the liability of natural person, liable person in legal person, and it can be, only logically, concluded that the accused natural person should be the first to present the views about the grounds of the charges/indictment against her/him (Sijerčić-Čolić et al, 2005, p. 933). This leads us to the conclusion that the prohibition of engagement of the same defence counsel cannot be logically justified, because the accused natural person will always attempt to contest the charges, and if she/he succeeds in doint so, that will, automatically, lift the charges against the legal person.

Another issue, speaking about the right to defence, is whether a legal person has right to mandatory defence. The LLPCO explicitly excludes implementation of provisions set forth by the Code on Criminal Procedure on mandatory defence in cases of legal persons being accused. This can be justified because it is impossible to satisfy listed legal conditions for mandatory defence of a natural person. Unfortunately, the same possibility is not foreseen by the $\mathrm{CPC} \mathrm{BiH}$. It foresees only the subsidiary implementation of the provisions referring to a natural person which includes provisions on mandatory defence (Article 387, CPC $\mathrm{BiH})$. Pursuant to the present analogy, a legal person should have the right to mandatory defence in case of a criminal offence that entails a conviction to a long term prison, or the time when the person is charged with a criminal offence for which he or she may be convicted to a prison sentence of ten or more years. However, since a legal person cannot be convicted to prison, the present provisions do not apply. The explanation given in the 
Commentaries to the $\mathrm{CPC} \mathrm{BiH}$ is not a satisfactory one. Namely, it reads that mandatory defence provisions exclusively refer to a natural person and that the right to a defence counsel for legal person is prescribed only as a possibility, rather than obligation. The cases where a legal person is charged with a criminal offence for which punishment may be ten years of imprisonment, or even more serious, are not elaborated. The implementation of other provisions on the right to mandatory defence is, naturally, excluded, because a legal person cannot be deaf or dumb, mentally ill, nor can the detention measure be pronounced (Đurđević, 2003, p. 763, footnote 178). It cannot be argued that the BiH legislator should have adopted the identical solution as the Croatian one thus removing all the possible dilemmas.

\subsection{Specific features of the main hearing course}

The derived responsibility of legal persons in criminal offences conditioned the change in sequence of actions referring the legal basis of the charges, course of the main hearing and presentation of evidence. The liable person, or natural person acting on behalf, in the interest or for the benefit of a legal person, shall have the priority in giving statement on the charges against the legal person representative. The same analogy applies to the presentation of evidence at the main hearing. At the main hearing, the priority in presenting evidence is given to the liable/natural person acting on behalf, in the interest or for the benefit of legal person. The modified sequence, in the course of the main hearings in both legislations, is justified since the criminal liability of legal persons is based on the criminal liability of natural persons with special status or powers. This is confirmed by the provisions on the sequence of closing addresses once the presenting of evidence has been finalized. The last final address always belongs to the liable person, or natural person who acted on behalf, in the interest, or for the benefit of a legal person, not to a legal representative or defence counsel of a legal person. It is obvious that the accused natural person enjoys a wider scope of rights than those of the accused legal person (Đurđević, 2003, p. 764).

\section{CONCLUSION}

The issue of criminal liability of legal persons was already a subject of numerous academic and expert discussion during the time of former SFRY. The authors, in that period, analysed the nature of economic transgressions (or corporate offenses) and their likeness to criminal offenses. However, the incentives for introduction of the criminal liability of legal persons failed. They were discouraged based on the Latin principle societas delinquere non potest due to the absence of mens rea that a legal person cannot have. The process of accession of former SFRY republics to European integration conditioned changes in national legislations and the introduction of criminal liability for legal persons. Bosnia and Herzegovina and Croatia adopted the model of derived liability. The fundamental postulate of the model is that the liability of a legal person for a criminal offense is derived from the criminal liability of a natural person and the unbreakable bond between the offender and legal person. However, regardless of the adoption of the same model, its implementation 
in the two legislations differs. The first evident distinction lies in the fact that Croatia decided to regulate criminal liability of legal persons by a special law, unlike Bosnia and Herzegovina, where these provisions are incorporated into the general substantive and procedural legislation. What is more essential than the distinctions in the legislative policies is the departure or deviations of relevant provisions concerning: conditions for establishing inseparable connection between the liability of a legal person and natural person, perpetrator of a criminal offense; comprehension and prescription of security measures; penal policy; implementation of single criminal procedure and the right of a legal person to a representative and a defence counsel. The inseparable connection, as a condition for criminal liability of a legal person exists, if it's responsible or liable person (Croatia) or person acting on its behalf, in its interest or to its benefit (Bosnia and Herzegovina) is proved to be guilty. Along this line, it is much easier to present evidence on criminal liability of a legal person, given the decisive provision prescribing that a legal person will be found guilty for criminal offenses committed by a natural person in charge of business affairs of the legal person, or a person who is entrusted with carrying out business affairs in its domain (legal definition of a liable person) under precisely prescribed conditions. To present conclusive proof that a natural person acted on behalf, in the interest or to the benefit of a legal person demands far more efforts without having legally prescribed what precisely this person should have done, or what status she/he should have had (Bosnia and Herzegovina). In view of the author, without entering into the analysis as to whether certain prohibitions should have been prescribed as security measures, or as possible legal consequences of the conviction against a legal person for a criminal offense, it would be necessary for Bosnia and Herzegovina to take over the solution of the Croatian legislator and set up a register of sanctions over legal persons. Based on the model of derived criminal liability of legal persons, it would be justified to have access to criminal register of legal persons, particularly giventhat the same already applies to natural persons.

In the analysed legislations, concerning penal policy, the probation period depends on the amount of a fine. It is necessary to amend the $\mathrm{CC} \mathrm{BiH}$ provision, which provides a suspended sentence against a legal person in case where the determined fine is not exceeding 1.500.000 BAM (Article 136, paragraph 2 of the $\mathrm{CC} \mathrm{BiH}$ ), because, in terms of criminal offenses, instead of being deterring, it is rather inciting.

In view of the right to defence, the amendments should go in two directions. The right to mandatory defence should be removed, which would eliminate all the legal ambiguities elaborated in the present analysis. Also, the right to a joint defence counsel for both legal and natural persons, because of the already adopted model of derived liability, should be adopted. Against the background of the adopted model and its postulates, the Croatian legislator should also take over the provision of the $\mathrm{CCP} \mathrm{BiH}$ and, consequently, the opportunity principle, which applies both in the case where the criminal offender is the only owner of the legal person, against whom criminal procedure would have been anyway instituted.

Finally, it is quite certain that, although the criminal liability of legal persons was introduced in both legislations seventeen years ago, the answer to most outstanding questions will be provided by case law only. 


\section{LIST OF REFERENCES}

Books, monographs and textbooks

Filipović, Lj. \& Ikanović, V. 2012. Criminal Procedure Against Legal Entities - educational module. Sarajevo: High Judicial and Prosecutorial Council of Bosnia and Herzegovina.

Sijerčić-Čolić, H. et al. 2005. The Commentaries on the Criminal Procedure Code of Bosnia and Herzegovina. Sarajevo: Council of Europe/European Commission.

Stajić, A \& Srzentić, N. 1961. Criminal law SFRY. General part. $3^{\text {rd }}$ ed. Belgrade: Modern Administration.

Stajić, A, Srzentić, N. \& Lazarević, Lj. 1984. Criminal Law SFRY. General Part. $12^{\text {th }}$ ed. Beograd: Modern Administration.

\section{Scholarly Articles}

Derenčinović, D. \& Novosel, D. 2012. Act on the Criminal Responsibility of Legal Entities -Temporary Childhood Diseases or the Squaring of the Circle? Croatian Annual of Criminal Sciences and Practice, Vol. 19-2, pp. 585-613.

Đurđević, Z. 2003. Criminal Liability and the Criminal Procedure for Legal Entities in the Republic of Croatia. Croatian Annual of Criminal Sciences and Practice, Vol. 10-2, pp. 719-770.

Perić, O. 1986. The Function of Corporate Offenses in Our Legal System and Elements for the Demarcation of other Categories of Punishable Delicts. Law-Theory and Pratice, No. 10-11, pp. 21-32.

Zlatarić, B. 1955. The Problems of Corporate Offences. Our Legality, No. 2, pp. 49-72.

\section{Legal sources}

Criminal Code of Bosnia and Herzegovina, Official Gazette of Bosnia and Herzegovina, No. 3/03, 32/03, 37/03, 54/04, 61/04, 30/05, 53/06, 55/06, 32/07,8/10, 47/14, 22/15, $40 / 15,35 / 18$.

Criminal Procedure Code of Bosnia and Herzegovina, Official Gazette of Bosnia and Herzegovina, No. 3/03, 32/03, 36/03, 26/04, 63/04, 13/05, 48/05, 46/06, 76/06, 29/07, $32 / 07,53 / 07,76 / 07,15 / 08,58 / 08,12 / 09,16 / 09,93 / 09,72 / 13,65 / 18$.

Directive (EU) 2017/1371 of the European Parliament and of the Council of 5 July 2017 on the fight against fraud to the Union's financial interests by means of criminal law. Available at: https://eur-lex.europa.eu/legal-content/hr/TXT/?uri=CELEX:32017L1371 (18. 8. 2020). 
Directive 2009/123/EC of the European Parliament and of the Council of 21 October 2009 amending Directive 2005/35/EC on ship-source pollution and on the introduction of penalties for infringements (Text with EEA relevance). Available at: https://eur-lex. europa.eu/legal-content/EN/TXT/?uri=celex\%3A32009L0123 (18. 8. 2020).

Law on economic transgressions, Official Gazette of the Federal People's Republic of Yugoslavia, No. 16/60.

Law on the Liability of Legal Persons for Criminal Offences, Official Gazette of the Republic of Croatia, No. 151/03, 110/07, 45/11, 143/12. 